\title{
How Did Covid-19 Affect Logistics Job Vacancy Postings?
}

Author(s): Ramazan Erturgut, Hasan Emin Gürler

Source: Journal of International Logistics and Trade 2021; 19(2):49-67

Published by: Jungseok Research Institute of International Logistics and Trade, Inha University DOI: https://doi.org/10.24006/jilt.2021.19.2.049

Journal of International Logistics and Trade is an official journal published by Jungseok Research Institute of International Logistics and Trade, Inha University, Korea. JILT welcomes manuscripts that advance the practice and science of logistics, trade, and other related fields.

Frequency: Quarterly (March, June, September, December)

Stable URL: https://www.ejilt.org

Jungseok Research Institute of International Logistics and Trade is a specialized academic research institute representing Inha University and Inha Foundation in Korea. The institute aims to become a representative institute in Northeast Asia in the research of logistics and trade.

Stable URL: https://jrieng.inha.ac.kr

(C) Copyright. Jungseok Research Institute of International Logistics and Trade.

This is an Open-Access article distributed under the terms of the Creative Commons Attribution NonCommercial License (http://creativecommons.org/licenses/by-nc/4.0/) which permits unrestricted noncommercial use, distribution, and reproduction in any medium, provided the original work is properly cited 



\title{
Journal of International Logistics and Trade
}

J. Int. Logist. Trade, 2021, Vol. 19, No. 2, 49-67

pISSN : 1738-2122 eISSN : 2508-7592

https://doi.org/10.24006/jilt.2021.19.2.049

\section{ARTICLE}

\section{How did Covid-19 Affect Logistics Job Vacancy Postings?}

\author{
Ramazan Erturgut, Hasan Emin Gürler* \\ Faculty of Applied Sciences, Akdeniz University, Antalya, Turkey
}

Received $\quad$ February 09, 2021
Revised $\quad$ March 26, 2021
Accepted April 19, 2021

*Corresponding author: Hasan Emin Gürler
Faculty of Applied Sciences, Akdeniz
University, Antalya, Turkey
Tel: +90-2422274400
E-mail: hasangurler@akdeniz.edu.tr

E-mail: hasangurler@akdeniz.edu.tr

\begin{abstract}
Human resources can differentiate firms from their competitors or directly affect the success or failure of firms. As in many sectors, there is a need for qualified employees in the logistics sector, which is of great importance for the national economies. Qualified employees in this sector contribute to the success of the companies and the development of the industry. In this study, it is aimed to reveal the qualifications and characteristics of the labour force needed by logistics companies. It was also aimed to show the impact of COVID19 on logistics job ads. For this purpose, a total of 1,410 job vacancy postings (before COVID-19) and a total of 1,700 job vacancy postings (during COVID-19) were searched on the kariyer.net website with the word "logistics" and analysed by content analysis method. As a result, it was found that the most advertised province was Istanbul in both periods, the most looked up experience requirement in the candidates was 1-5 years in both periods, the opportunities provided to the candidates (transportation, food and beverage, career, social activity) were not mentioned much in both periods. This study reveals the status of logistics job postings in the period before COVID-19 and during COVID-19. It was also aimed to show the impact of COVID-19 on logistics job ads. We investigated whether the logistics employee demand has changed and whether the pandemic is affecting workforce characteristics. This is the first empirical analysis of the impact of COVID-19 on logistics vacancy postings.
\end{abstract}

Keywords Logistics, Job vacancy postings, COVID-19, Content analysis

\section{Introduction}

Technological developments, globalisation and intense competition due to them make it compulsory for companies to update themselves and adapt to changes constantly. However, it is not enough for companies to have the latest technology, and they need human resources to contribute to the company's processes and value by using the current technology in the most effective way (Yücel and Bal 2018). Similarly, technological developments have led to the emergence of different practices in many areas. One of these various practice examples has been related to the selection of employees. While methods such as newspaper advertisements and employee references have been used in the procurement of employees previously, the choice of the employees has now started to be made electronically with the effect of technological changes and developments (Çetin and Akar Şahingöz 2019). Firms' websites and career sites have become important tools used in the electronic procurement of employees (Yücel and Bal 2018). Thanks to this method, the supply of employees take less time and are lower cost (Öksüz 2011).

With the increasing impact of the service industry on the country's economies, employment in this industry is also increasing. The logistics sector is one of the industries that grow in importance and creates work in the service industry (Koban and Keser 2013). Employment in the sector is expected to increase by 7\% between 2016-2026 (BLS 2019). As in most countries, the service sector in Turkey has become more important over time. This remarkable increase has greatly influenced the growth momentum of the Turkish logistics sector, the importance of which has increased in recent years. When evaluating the employment aspect, the logistics industry is one of the highest employment generating services sector in Turkey's economy (Koban and Keser 2013). When the transportation and storage services that characterize the logistics sector among the basic 
indicators of TUIK are evaluated, the number of people employed in the sector decreased by $2.5 \%$ compared to the previous year and became 927405 as of January 2021 (TUIK 2021). The logistics sector can promote economic growth as well as employing a large part of the population. While high economic welfare provides efficiency in logistics, effective logistics activities can actively contribute to economic prosperity (Waters 2003). While this sector is of great importance for the competitiveness of the countries, having qualified employees plays an important role in the achievement of the competitive advantage of the nations (Koban and Keser 2013). Therefore, logistics companies operating in the sector need qualified personnel not only to keep up with technology and supply chain operational changes but also to ensure that logistics activities are low cost and sustainable for customers (Klumpp 2016).

Academic research offers a range of skills and qualifications for logistics managers, which are skills and capabilities that are evaluated and developed based on the experience of logistics managers or students (Kotzab et al. 2018). Particularly, in the last 25-30 years, researches that draw attention to various skills that logistics managers should possess have been conducted (D’Alessandro 2018; Gibson and Cook 2001; Kovács et al. 2012; LaLonde 1990; Lin and Chang 2018; Murphy and Poist 1991; Poist et al. 2001; Razzaque and Sirat 2001; Trunick 1998; Wu et al. 2004). However, it is seen that there are a few studies on logistics job ads in foreign literature, but there is no research on logistics job ads in the domestic literature. Therefore, with this study, it is aimed to reveal which qualities and characteristics of logistics companies need workforce and the features and qualities that potential employees who continue their education life in the field or who have completed their education life should have.

COVID-19 negatively affected life in many areas. It has caused changes in the way businesses to do business. The country's economies, international trade and logistics activities have significantly affected. Also, many publications have been made about this disease in many areas (Daniel 2020; Lau et al. 2020; Sun et al. 2020a), especially in health (Cao 2020; Cullen et al. 2020; Pfefferbaum and North 2020). This study was originally considered without the COVID-19 effect. It is mainly designed to review logistics job ads. The data was obtained in July 2019, and it took a long time to complete the content analysis and to complete the study overall. But during COVID-19 appeared, three questions arose in our minds:

-Will this disease affect the logistics job ads in Turkey? According to TUIK, the number of people employed in the sector decreased by $2.5 \%$ compared to the previous year. Did COVID-19 have an impact on this decline? Is it possible to observe the decline in logistics job vacancy postings?

- If so, in what aspects this effect will be?

- Will there be a reduction in the number of job ads?

- Did digitalisation, which has become more important with COVID-19, affect job ads and the characteristics and qualifications sought from candidates in job ads?

Based on these questions, we redesigned the study to examine and compare job ads before and during COVID-19. Accordingly, we reviewed the job ads literature with the focus of COVID-19. In the findings section, we presented comparative tables and graphs showing the status of logistics job ads before and during COVID-19. Thus, it will be possible to see whether the conditions sought in candidate employees differ due to COVID-19 and which vacancies need more employees. Also, it is possible to see which of the conditions sought in candidates come to the fore with the effect of the pandemic.

\section{Literature}

The main and most important source of production and service enterprises is human. Although it has similar production equipment and similar production processes, it is the human resource that causes the enterprises to differ from each other, to succeed or fail. For this reason, the selection of qualified employees is extremely important for businesses in an environment where competition is intense. Employee selection is the process of choosing among candidates who apply for vacant positions, which are determined according to the definition and requirements of the job (Temiz and Cingöz 2015). In this process, the company can benefit from internal resources (promotion, transfer) as well as provide suitable and qualified employees for vacant positions from outside the firm. Also, the selection process consists of different stages, and these stages may vary according to the other characteristics of the enterprises (business size, number of personnel, etc.) and the job (Çavdar and Çavdar 2010).

Logistics and supply chain management play a critical role in the economy of each country. As in other economic sectors, a skilled workforce contributes greatly to the success of the industry in the logistics and supply chain sector. As the business 
environment continues to change rapidly, companies operating in the logistics and supply chain sector face many challenges where the need for well-trained and skilled logistics professionals is necessary (Thai et al. 2011). However, the demand for people who will work in the logistics and supply chain industry is constantly increasing, and it is increasingly difficult to find qualified personnel for blue-collar and white-collar jobs (Kotzab et al. 2018). Firms operating in the logistics sector face a critical shortage of talent due to the global lack of supply chain professional skills. In a study conducted by the logistics provider in $2015,50 \%$ of the respondents stated that they had difficulty in finding supply chain experts (D'Alessandro 2018). For this reason, it is vital for an organisation looking for logistics professionals to define an adequate work profile, a combination of skills and competencies that enable changes to the work profile to be made rapidly in an increasingly temporary environment (Kotzab et al. 2018).

There are many publications on job advertisements in the literature and in Table 1, some of the previous studies on the examination of job advertisements in domestic and foreign literature are included. When the table is analysed, it is seen that there are publications regarding job ads given by logistics companies in foreign literature. At the same time, there is no study in the local literature regarding job ads with logistics theme. In their research on job ads, Kovács et al. (2012) examined the humanitarian logistics representatives posted on the "ReliefWeb" website between January 2010 and March 2010. They aimed to demonstrate the qualifications that humanitarian logistics should have. The researchers, who examined 180 job ads in total with the content analysis method, found that humanitarian logistics companies should have broad functional skills (supply, warehouse and transportation management) and contextual skills such as safety management and comprehensive knowledge of donor regulations. In their study of job ads, Cacciolatti and Molinero (2013) examined the 510 job ads they accessed on the "jobs4supplychain.com" website between 01.05.2011-30.06.2011 using the keyword supply chain management. They used the sequential multidimensional scaling and cluster analysis method in the analysis of the data. As a result, they found that advertisements can be defined in six dimensions, and candidates are asked to have analytical skills and problem-solving skills. In their study on job ads, Kotzab et al. (2018) examined the logistic job ads on the websites "Stepstone", "Jobpilot" and "Xing" using content analysis and thematic mapping methods. The researchers, who examined 1,000 job ads in total, as a result, found that social skills were at the forefront in the academic literature, but that the cognitive competence and meta-competence were sought in the candidates for the advertisements they examined differently from the literature.

The research we have mentioned so far has been done before COVID-19. There are also studies conducted to determine the impact of COVID-19 on job ads. Holgersen et al. (2020) examined job ads in the Norwegian Labor and Welfare Administration database. Researchers who examined job ads in the February-June period found that job ads decreased by $27 \%$ compared to the previous year. They found that job ads for almost all industries and professions were significantly reduced, regardless of whether they could be carried out remotely. Kahn et al. (2020) examined the job ads given to Burning Glass Technologies company between 19 January and 29 February 2020. Just as Holgersen et al. (2020) have found, researchers have found that job ads are decreasing for virtually all industries and professions, regardless of whether or not they can work from home. Also, researchers have found that there are exceptions to this situation in two important areas: retail and nursing. Researchers have determined that these two sectors are the ones hosting the "front line" jobs that are most in-demand during the pandemic. Hensvik et al. (2020) examined job ads in the database of Platsbanken, Sweden's important online job search platform, between January and April 2020. They found those job ads decreased by $40 \%$ in Sweden, job ads for health services increased, and candidates generally applied for jobs with remote employment opportunities. Overall, they predicted that the current situation has the potential to increase labour demand shock.

There are also studies on the effects of COVID-19 on supply chains, logistics systems and transportation. For example, Guan et al. (2020) analyzed global supply chains in countries taking trade-related measures under COVID-19. Aday and Aday (2020) examined the impact of COVID-19 on the food supply chain and made recommendations to reduce the impact of the pandemic. Singh et al. (2020) created three different scenarios to show the disruptions caused by COVID-19 in the food supply chain and developed a simulation model of the public distribution system network. Loske (2020) analyzed the impact of COVID-19 on transport volume and freight capacity in the food supply chain. Sun et al. (2020b) analyzed the impact of COVID-19 on the international air transport industry with the help of complex networks. Donthu and Gustafsson (2020) examined the effects of COVID-19 on different industries, changes in consumer behaviour and businesses, and its impact on employees and leadership.

With this study, it is possible to see the effect (if any) of COVID-19 on logistics job ads. Also, it will be possible to have an idea about what qualities and characteristics of logistics companies need a workforce. At the same time, the features and qualities that potential employees who continue their education life or have completed their education life should be mentioned. It is anticipated that the findings of this study will contribute to the field, especially since research on the subject is limited in the domestic literature. 
Table 1. Previous research related to job ads

\begin{tabular}{|c|c|c|c|}
\hline Researcher & Field/sector & Scope & \# of ads \\
\hline Peres and Meivar 1986 & General & $\begin{array}{l}\text { Ma'ariv newspaper, January 1949- } \\
\text { December } 1978\end{array}$ & 1,800 \\
\hline Todd et al. 1995 & Information systems & $\begin{array}{l}\text { The Wall Street Journal, The New York } \\
\text { Times, The Globe, The Toronto Star, } \\
\text { 1970-1990 }\end{array}$ & 1,634 \\
\hline Keung and Pine 2000 & Tourism & $\begin{array}{l}\text { South China Morning Post, January 1987- } \\
\text { December } 1997\end{array}$ & 1,552 \\
\hline Clyde 2002 & Education (library) & LIBJOBS, 01.12.2001-28.02.2002 & 150 \\
\hline Bennett 2002 & $\begin{array}{l}\text { Marketing, human resources, } \\
\text { finance, business management }\end{array}$ & $2000-2001$ & 1,000 \\
\hline Croneis and Henderson 2002 & Education (library) & $\begin{array}{l}\text { College \& Research Libraries News, } \\
\text { 1990-2000 }\end{array}$ & 223 \\
\hline Gallavin et al. 2004 & Information technologies & $\begin{array}{l}\text { Computer World and the Atlanta Journal } \\
\text { Constitution, 1988, 1995, 2001, 2002, } \\
2003\end{array}$ & 2,297 \\
\hline Sodhi and Son 2010 & Operational research & $\begin{array}{l}\text { Monster.com, Hotjobs.com, OR/MS } \\
\text { Today, 1999-2005 }\end{array}$ & 1,056 \\
\hline Kovács et al. 2012 & Humanitarian logistics & ReliefWeb, January-March 2010 & 180 \\
\hline Cacciolatti and Molinero 2013 & Supply chain management & $\begin{array}{l}\text { jobs4supplychain.com, 01.05.2011- } \\
30.06 .2011\end{array}$ & 510 \\
\hline Bacaksız and Sönmez 2015 & Health & Three websites, 24.09.2013 & 750 \\
\hline Beltekin 2014 & General & Kariyer.net, 7.11.2013-27.12.2013 & 100 \\
\hline Grigoriadis 2014 & Supply chain management & $\begin{array}{l}\text { www.graduateland.com, } \\
\text { www.linkedin.com, February-August } \\
2014\end{array}$ & 63 \\
\hline Erdem and Gezen 2014 & Tourism & $\begin{array}{l}\text { Two newspapers, four websites, } 20 \\
\text { September-8 October } 2012\end{array}$ & 1,421 \\
\hline $\mathrm{Al}$ et al. 2015 & Executive assistant & Kariyer.net & 500 \\
\hline Özdemir et al. 2015 & Tourism & Turizmgazatesi.com, 1-31 March 2015 & 524 \\
\hline Bayraktar 2015 & General & Seven Ottoman newspapers, 1909-1924 & 125 \\
\hline Kılınç and Akyol 2018 & Corporate communications & Kariyer.net, 1-4 August 2017 & 72 \\
\hline Özkan et al. 2018 & Informatics & Three websites, 01.01.2017-31.12.2017 & - \\
\hline Türkal and Taşcıoğlu 2018 & Public relations & $\begin{array}{l}\text { Kariyer.net, November } 14 \text { - December 14, } \\
2017\end{array}$ & 1,167 \\
\hline Kotzab et al. 2018 & $\begin{array}{l}\text { Logistics and supply chain } \\
\text { management }\end{array}$ & Stepstone, Jobpilot, Xing & 1,000 \\
\hline Ertaş 2018 & Tourism & $\begin{array}{l}\text { Turizmgazatesi.com, } 17 \text { March 2018-21 } \\
\text { June } 2018\end{array}$ & 1,927 \\
\hline Çetin and Akar Şahingöz 2019 & Food & $\begin{array}{l}\text { Kariyer.net, Yenibiris.com, İndeed.com, } \\
\text { İsbul.net, 06.10.2018-19.11.2018 }\end{array}$ & 665 \\
\hline Doğan and Tuncer 2019 & Tourism & $\begin{array}{l}\text { Kariyer.net, 2-17 February 2018-1-16 } \\
\text { August } 2018\end{array}$ & 160 \\
\hline Türkal and Taşcıoğlu 2020 & Public relations & $\begin{array}{l}\text { Eleman.net, Elemanonline, Yenibiriş, } \\
\text { Kariyer.net, İşbul 2018-Aralık }\end{array}$ & 2,232 \\
\hline Yilmaz 2020 & Lodging enterprises & Kariyer.net, 24.09.2019-08.10.2019 & 124 \\
\hline This study & Logistics & $\begin{array}{l}\text { Kariyer.net, before COVID-19 } \\
\text { (11.07.2019-18.07.2019), during COVID- } \\
19(13.07 .2020-20.07 .2020)\end{array}$ & $\begin{array}{l}\text { Before COVID-19: } \\
\text { 1,410 ads, } \\
\text { during COVID-19: } \\
1,700 \text { ads }\end{array}$ \\
\hline
\end{tabular}

\section{Data and methodology}

In this study, the content analysis method is used to analyse the job vacancy postings posted by logistics companies operating 
in Turkey. Content analysis was defined by Holsti (1969) as the application of scientific methods to documentary evidence (Duncan 1989). This method is the process of systematically analysing messages of any type of communication. Content analysis is used to make objective inferences about the subject of interest. The content analysis process consists of raw coding messages (i.e., textual material, visual elements, images) according to a classification scheme. Words, terms, theories, topics, concepts or other characteristics can be used as components in content analysis (Kondracki et al. 2002).

Content analysis involves measuring how often certain attributes in a document appear. Modern content analysis was largely developed by Harold D. Lasswell et al. in their work on the political content of newspapers in the late 1930s. This method, which was originally called "symbol analysis", was used to reveal the frequency of certain keywords such as "Germany" or "Jews" appearing in newspaper content (Duncan 1989). There are many studies in the literature using the content analysis method (Dobroszek et al. 2019; Finn and Strickland 1982; Gaur and Kumar 2018; Giglietto and Selva 2014; Hartsough and Laffal 1970; Heske 1986; Larson 1974; Mastro and Stern 2003; Peterson 1994; Stead 1978; Stevenson and Swayne 2011; Tu and Lin 1999; Wang et al. 2016; Worthington et al. 2007).

The data was obtained from the job ads of logistics companies posted on the Kariyer.net website. Kariyer.net website has been preferred due to the largest employment platform, which has 400 employees, 17 offices and 94 thousand members since 1999 in Turkey (Kariyer 2019). Logistics job ads were obtained by searching the word "logistics" between 11.07.201918.07.2019 (before COVID-19) and 13.07.2020-20.07.2020 (during COVID-19). In the process of getting the data, it was seen that there was more than one job posting by the same company. Still, each one was evaluated separately, since it was understood that each job posting required different conditions and qualifications. However, it was noticed that there were duplicate advertisements, and only one of these job ads was taken into consideration. As a result, a total of 1,410 job ads (before COVID19) and a total of 1,700 job ads (during COVID-19) that are submitted by logistics companies are analysed using the content analysis method. The statistical package program was used to analyse the job ads with the content analysis method.

Job ads are classified according to the following items. The classification was made based on the studies of Bacaksiz and Sönmez (2015), Çetin and Akar Şahingöz (2019), Erdem and Gezen (2014), and Yilmaz (2020).

- Province, sector, job position, department, experience, education level, manner of work, advertisement language.

- Main features required in candidates (gender, department graduated, foreign language knowledge, computer knowledge, travel disability, driving license, military status, place of residence).

- Opportunities offered to candidates (transportation, food and beverage, career, social activity).

- Special qualities sought in candidates (adaptation to teamwork, adaptation to working hours, leadership ability, ability to communicate, analytical thinking skills, planning and organisational skills, problem-solving skills, ability to take responsibility).

- Other qualities that stand out in job ads.

After this classification, frequency analysis was made, and the expressions in the job ads were examined. However, the association rule proposed by Agrawal et al. (1993) was used to determine which of the features or qualifications in the job ads were stipulated in the same ad together. The association rule is widely used in determining the purchasing habits of the customers by finding the association relationships between the products that the customers purchase (Doğan et al. 2014). The association rule is used for different purposes in different sectors such as traffic accidents (Söylemez et al. 2016), insurance (Doğan et al. 2014), and business intelligence solutions (Birant et al. 2010). Based on these application examples, we think that the common features or qualities sought in job ads can also be examined within the scope of the association rule. Using this rule, it is aimed to determine which qualification or feature pairs the candidates should have. While obtaining qualification or feature pairs following the association rule, coding was made on the same package program, and frequencies of the qualification or feature pairs were determined. In determining the feature or quality pairs, deductions have been made from the literature, since there is no study in which similar encodings were made on the subject. For example, based on the word adaptation, it is coded together with two features such as "adaptation to working hours" and "adaptation to teamwork". These qualification or feature pairs obtained both before COVID-19 and during COVID-19 are presented in Figure 1, Figure 2, and Figure 3.

\section{Results}

The distribution of the job ads examined by provinces is shown in Table 2. When the table is analysed, it is seen that the highest number of job ads were made from Istanbul in both periods. It is observed that six of the nine provinces with the highest 
Table 2. Distribution of job ads by provinces

\begin{tabular}{|c|c|c|c|c|c|}
\hline \multicolumn{3}{|c|}{ Before COVID-19 } & \multicolumn{3}{|c|}{ During COVID-19 } \\
\hline Province & \# of job ads & $\%$ & Province & \# of job ads & $\%$ \\
\hline İstanbul & 906 & 64.26 & İstanbul & 1,018 & 59.88 \\
\hline Kocaeli & 111 & 7.87 & İzmir & 151 & 8.88 \\
\hline İzmir & 96 & 6.81 & Ankara & 151 & 8.88 \\
\hline Bursa & 89 & 6.31 & Kocaeli & 146 & 8.59 \\
\hline Ankara & 79 & 5.60 & Bursa & 96 & 5.65 \\
\hline Antalya & 41 & 2.91 & Mersin & 44 & 2.59 \\
\hline Tekirdağ & 32 & 2.27 & Tekirdağ & 32 & 1.88 \\
\hline Eskişehir & 30 & 2.13 & Konya & 31 & 1.82 \\
\hline Manisa & 26 & 1.84 & Sakarya & 31 & 1.82 \\
\hline Total & 1,410 & 100.00 & Total & 1,700 & 100.00 \\
\hline
\end{tabular}

number of job ads in both periods were the same. Among these six provinces, Tekirdağ is the only province whose number of job ads did not increase compared to the previous period (before: 32, during: 32). It can be said that the number of job ads in Mersin, Konya, and Sakarya provinces has increased significantly in the period during COVID-19. It is observed that there is an increase in the number of job ads in general.

Table 3 shows the distribution of job ads by sectors. When the table is analysed, it is seen that the industry with the most job ads is the transportation sector in both periods. The second sector with the most job ads for both periods is the logistics sector. It is observed that the number of job ads for both sectors has increased significantly during COVID-19. It is observed that seven of the nine industries with the highest number of job ads in both periods were the same. Among these seven sectors, the two sectors whose number of job ads decreased compared to the previous period are the textile, and international transport and shipping sectors.

The positions sought in job ads are given in Table 4. While the most desired position in the period before COVID-19 was Logistics Specialists, the most sought work in the period during COVID-19 was Sales Representative. In the logistics and supply chain sector, it is seen that companies need sales representatives to meet the demand due to COVID-19 and job vacancy postings in this field have increased (CBS 2021). Delivery cancellations and delays occur when offices and factories close due to COVID-19. This results in working from home or not coming face to face with the customer. In such a business environment, the salesperson can talk to a potential customer and work faster and more cost-effectively than traditional call centers or faceto-face agents can (BCG 2020). It is observed that half of the ten positions with the highest number of job ads in both periods were different. It can be said that the work to be employed has changed, albeit partially, for the period during COVID-19. It

Table 3. Distribution of job ads by sectors

\begin{tabular}{|c|c|c|c|c|c|}
\hline \multicolumn{3}{|c|}{ Before COVID-191) } & \multicolumn{3}{|c|}{ During COVID-192) } \\
\hline Sector & \# of job ads & $\%$ & Sector & \# of job ads & $\%$ \\
\hline Transportation & 351 & 24.89 & Transportation & 476 & 28 \\
\hline Logistics & 257 & 18.23 & Logistics & 363 & 21.35 \\
\hline Textile & 117 & 8.30 & Production / industrial products & 144 & 8.47 \\
\hline Production / industrial products & 109 & 7.73 & Commerce & 132 & 7.76 \\
\hline $\begin{array}{l}\text { International transport and } \\
\text { shipping }\end{array}$ & 103 & 7.30 & Informatics & 107 & 6.29 \\
\hline Automotive & 73 & 5.18 & Textile & 100 & 5.88 \\
\hline Informatics & 61 & 4.33 & Automotive & 86 & 5.06 \\
\hline Service & 59 & 4.18 & $\begin{array}{l}\text { International transport and } \\
\text { shipping }\end{array}$ & 84 & 4.94 \\
\hline Chemistry & 58 & 4.11 & E-commerce & 81 & 4.76 \\
\hline Other & 222 & 15.74 & Other & 127 & 7.47 \\
\hline
\end{tabular}

${ }^{1)}$ The number of ads for each sector in the other category is less than 58. This is valid for all following tables in which the other type is included.

${ }^{2)}$ The number of ads for each sector in the other category is less than 81 . This is valid for all following tables in which the other type is included. 
Table 4. Distribution of job ads by positions

\begin{tabular}{|c|c|c|c|c|c|}
\hline \multicolumn{3}{|c|}{ Before COVID-19 } & \multicolumn{3}{|c|}{ During COVID-19 } \\
\hline Position & \# of job ads & $\%$ & Position & \# of job ads & $\%$ \\
\hline Logistics specialists & 43 & 3.05 & Sales representative & 452 & 26.59 \\
\hline Assistant logistics specialist & 43 & 3.05 & Storage supervisor & 208 & 12.24 \\
\hline Sales expert & 41 & 2.91 & Logistics specialists & 164 & 9.65 \\
\hline Sales representative & 41 & 2.91 & Storage element & 141 & 8.29 \\
\hline Storage element & 35 & 2.48 & Sales director & 129 & 7.59 \\
\hline Foreign trade chief & 33 & 2.34 & Logistics supervisor & 123 & 7.24 \\
\hline Foreign trade specialist & 30 & 2.13 & Buying specialist & 117 & 6.88 \\
\hline Logistics supervisor & 24 & 1.70 & Foreign trade specialist & 105 & 6.18 \\
\hline Export operation specialist & 23 & 1.63 & Foreign trade supervisor & 101 & 5.94 \\
\hline Sales director & 22 & 1.56 & Driver & 99 & 5.82 \\
\hline Other & 1,041 & 73.83 & Other & 61 & 3.59 \\
\hline
\end{tabular}

would not be wrong to say that the number of job ads for almost all positions has increased significantly except the Assistant Logistics Specialist, Sales Expert, Foreign Trade Chef, Export Operation Specialist, and Sales Director positions.

Table 5 shows the distribution of job ads by departments. When the table is analysed, it is seen that the department that has the highest number of job ads is logistics in both periods. Also, the first five departments with the most job ads in both periods are the same. It is observed that six of the nine departments with the highest number of job ads in both periods were the same. It can be said that the number of job ads in these six departments has increased significantly. It is seen that the job ads for Sales and Marketing, Purchase, and Information Technologies departments have increased compared to the previous period.

Table 6 shows whether there is a requirement for experience in the job ads, and if so, how many years. When the table is analysed, it can be said that the number of job ads for which 1-5 years and 6-10 years of experience are required has increased compared to the period before COVID-19. The number of job ads without experience has also increased relatively. It is seen that the number of job ads for which 11-15 years of experience is required has decreased compared to the period before COVID19. However, it has been determined that there is no requirement for 16-20 years and 21-25 years of experience in the job ads in both periods.

Table 7 shows the level of education required for candidates in job ads. When the table is examined, it is stipulated that the education levels of the candidates must be a bachelor's degree (before: 1,216 job ads, during: 1,440 job ads) in both periods. Other requirements for education level are as follows in the period before COVID-19: Master degree (628 job ads), associate degree (486 job ads), Ph.D. (306 job ads), high school (264 job ads), and primary education (39 job ads). Also, it is seen that there are job ads for students who continue their education life. It has been determined that 417 of these ads are candidates' graduate students, 267 of them are doctoral students, 146 of them are undergraduate students, 87 of them are associate degree students, and 17 of them are high school students.

Table 5. Distribution of job ads by departments

\begin{tabular}{|c|c|c|c|c|c|}
\hline \multicolumn{3}{|c|}{ Before COVID-19 } & \multicolumn{3}{|c|}{ During COVID-19 } \\
\hline Department & \# of job ads & $\%$ & Department & \# of job ads & $\%$ \\
\hline Logistics & 78 & 5.53 & Logistics & 413 & 24.29 \\
\hline Import / export & 30 & 2.13 & Import / export & 148 & 8.71 \\
\hline Depot / warehouse & 27 & 1.91 & Depot / warehouse & 127 & 7.47 \\
\hline Operation & 25 & 1.77 & Operation & 123 & 7.24 \\
\hline Sales & 22 & 1.56 & Sales & 92 & 5.41 \\
\hline Transport & 18 & 1.28 & Sales and marketing & 95 & 5.59 \\
\hline Shipping & 18 & 1.28 & Purchase & 72 & 4.24 \\
\hline Manufacturing / production & 17 & 1.21 & Manufacturing / production & 52 & 3.06 \\
\hline Data processing & 13 & 0.92 & Information technologies & 50 & 2.94 \\
\hline Other & 1,150 & 81.56 & Other & 528 & 31.06 \\
\hline
\end{tabular}


Table 6. Distribution of job ads by experience

\begin{tabular}{|c|c|c|}
\hline \multirow{2}{*}{ Job experience } & \multicolumn{2}{|c|}{ \# of job ads } \\
\hline & Before COVID-19 & During COVID-19 \\
\hline $1-5$ years & 949 & 1,193 \\
\hline $6-10$ years & 71 & 93 \\
\hline $11-15$ years & 4 & 1 \\
\hline 16-20 years & - & - \\
\hline $21-25$ years & - & - \\
\hline No experience & 386 & 413 \\
\hline
\end{tabular}

Table 7. Education level requirement

\begin{tabular}{lcr}
\hline \multicolumn{1}{c}{ Education level } & \multicolumn{2}{c}{ \# of job ads } \\
\cline { 2 - 3 } High school student & Before COVID-19 & During COVID-19 \\
Vocational school student & 17 & 59 \\
University student & 87 & 134 \\
Graduate student & 146 & 329 \\
Ph.D. student & 417 & 156 \\
Primary education & 267 & 96 \\
High school & 39 & 452 \\
Associate degree & 264 & 662 \\
Bachelor's degree & 486 & 1,440 \\
Master degree & 1,216 & 571 \\
Ph.D. & 628 & 209 \\
\hline
\end{tabular}

Some job ads require at least two different education level.

Other requirements for education level are as follows in the period during COVID-19: Associate degree (662 job ads), master degree (571 job ads), high school (452 job ads), Ph.D. (209 job ads), and primary education (96 job ads). Also, it is seen that there are job ads for students who continue their education life. It has been determined that 329 of these ads are candidates' graduate students, 180 of them are undergraduate students, 156 of them are doctoral students, 134 of them are associate degree students, and 59 of them are high school students.

The manner of work included in the job ads are given in Table 8 . When the table is examined, it is seen that the way of working in most of the job ads is full time in both periods. The number of job ads for which full-time employment is required has increased. The number of job ads for which other forms of work are needed has decreased significantly.

Table 9 contains information about the language in which job ads are made. When the table is analysed, it is seen that 1,337 job ads were given in Turkish and 73 job ads in English in the period before COVID-19. Also, 1,640 job ads were presented in Turkish and 60 job ads in English in the period during COVID-19. In the post-pandemic period, the number of job ads posted in Turkish increased, while the number of job ads published in English decreased slightly.

In Table 10, the basic features sought in candidates are given. When the table is analysed, it can be said that most of the job ads posted in the period during COVID-19 are for men. The number of job ads that require the ability to speak or correspond in English appears to have increased significantly. It is also observed that the number of job ads for which knowledge of package

Table 8. Manner of work

\begin{tabular}{lcr}
\hline \multirow{2}{*}{ Manner of work } & \multicolumn{3}{c}{ \# of job ads } \\
\cline { 2 - 4 } Full time & Before COVID-19 & During COVID-19 \\
Trainee & 1,346 & 6 \\
Periodic / project based & 28 & 13 \\
Part-time & 27 & 2 \\
\hline
\end{tabular}


Table 9. Job ads languages

\begin{tabular}{ccc}
\hline & & \# of job ads \\
\cline { 2 - 3 } Language & Before COVID-19 & During COVID-19 \\
Turkish & 1,337 & 1,640 \\
English & 73 & 60 \\
\hline
\end{tabular}

Table 10. Key features of candidates

\begin{tabular}{|c|c|c|}
\hline \multirow{2}{*}{ Key features } & \multicolumn{2}{|c|}{ \# of job ads } \\
\hline & Before COVID-19 & During COVID-19 \\
\hline \multicolumn{3}{|l|}{ Gender } \\
\hline Female & 84 & 184 \\
\hline Male & 241 & 723 \\
\hline Unspecified & 1,085 & 793 \\
\hline \multicolumn{3}{|l|}{ Foreign language } \\
\hline English & 604 & 1,036 \\
\hline Other & 11 & 5 \\
\hline Unspecified & 795 & 659 \\
\hline \multicolumn{3}{|l|}{ Computer skills } \\
\hline MS office programs & 149 & 352 \\
\hline Package programs & 213 & 466 \\
\hline Unspecified & 1,048 & 882 \\
\hline \multicolumn{3}{|l|}{ Travel disability } \\
\hline Specified & 202 & 696 \\
\hline Unspecified & 1,208 & 1,004 \\
\hline \multicolumn{3}{|l|}{ Driver's license } \\
\hline Specified & 168 & 541 \\
\hline Unspecified & 1,242 & 1,159 \\
\hline \multicolumn{3}{|l|}{ Military service } \\
\hline Specified & 286 & 449 \\
\hline Unspecified & 1,124 & 1,251 \\
\hline \multicolumn{3}{|l|}{ Place of residence } \\
\hline Specified & 271 & 340 \\
\hline Unspecified & 1,139 & 1,360 \\
\hline
\end{tabular}

and MS Office programs is required has increased. It would not be wrong to say that the number of job ads with a requirement regarding travel disability, driver's license, military status, and place of residence has increased significantly.

Considering the association rule, four groups have been formed regarding the basic features sought in candidates in both periods. Group 1: Foreign Language and Computer Skills (only one-MS Office Programs or Package Programs), Group 2: MS Office Programs and Package Programs, Group 3: Travel Disability-Driver's License Group 4: Military Service-Place of Residence. The figure created by groups is below.

As can be seen in Figure 1, the number of job ads, in which both foreign language knowledge and computer skills are required together is higher in both periods. The number of job ads, in which both MS Office programs and package programs are stipulated together has increased significantly in the period during COVID-19. The number of job ads for which travel disability and driver's license is required together has increased, with the highest increase in the number of job ads in this group. The number of job ads for which military service and place of residence are required together has increased, but the least increase in the number of job ads was in this group. Figure 1 shows that while foreign language knowledge and computer skills maintain their importance, travel disability and driver's license has become an important requirement in the period during COVID-19.

Table 11 shows the opportunities promised to candidates in job ads. When the table is examined, there has been an increase in the number of job ads that specified transportation, cenation, career, and social activity opportunities. In particular, the rise in the number of ads where cenation and career opportunities were specified was higher. 


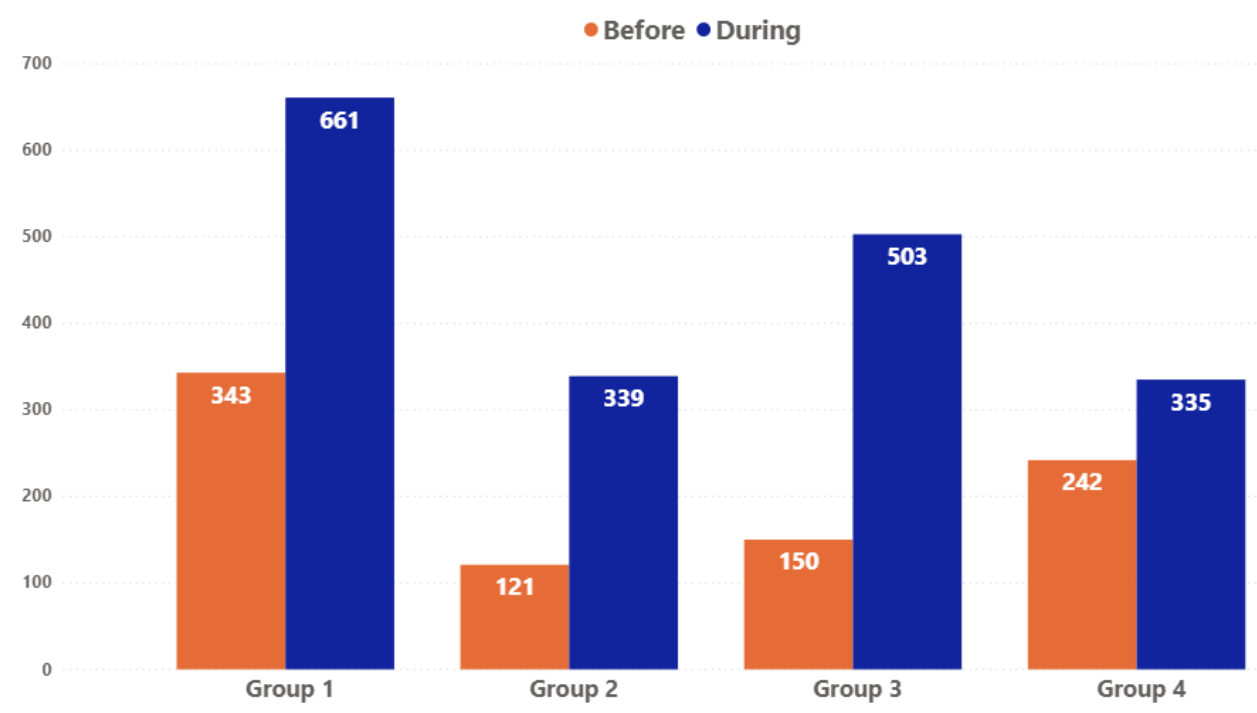

Figure 1. Groups by basic features.

Table 11. Opportunities for candidates

\begin{tabular}{lcr} 
& & \\
Opportunitiy & \# of job ads \\
\cline { 2 - 3 } Transportation opportunity & 28 & During COVID-19 \\
$\quad$ Specified & 1,382 & 124 \\
$\quad$ Unspecified & & 1,576 \\
Cenation opportunity & 79 & 367 \\
$\quad$ Specified & 1,331 & 1,333 \\
Unspecified & 18 & 408 \\
Career opportunities & 1,392 & 1,292 \\
$\quad$ Specified & & \\
Unspecified & 2 & 84 \\
Social activity opportunity & 1,408 & 1,616 \\
Specified & & \\
Unspecified & & \\
\hline
\end{tabular}

Table 12 shows the special qualifications sought for candidates. When the table is examined, it is seen that except for adaptation to working hours, there has been a significant increase in the number of job ads where all other special qualifications are specified. Special qualification with the highest growth in the number of job ads is an adaptation to teamwork in the period during COVID-19. The special qualification, which is the least increase in terms of the number of job ads, is the planning and organisation skill.

Considering the association rule, five groups have been formed regarding the Special qualifications required for candidates in both periods. Group 1: "Adaptation to Team Work" and "Adaptation to Working Hours", Group 2: "Leadership Ability" and "Communication Ability", Group 3: "Analytical Thinking Skill” and "Planning and Organization Skill”, Group 4: "Problem Solving Ability" and "Ability to Take Responsibility", Group 5: All special qualifications mentioned in Table 12. The figure created by groups is below.

As can be seen in Figure 2, the number of job ads, in which both problem-solving ability and ability to take responsibility are required together is higher in both periods. The number of job ads, in which both adaptations to teamwork and adaptation to working hours, are specified together has decreased. There were increases in all groups except group 1. The biggest reason for the decline in group 1 is that adaptation to working hours was not required in most job ads in the period during COVID-19. The number of job ads for which leadership ability and communication ability are required together has increased, with the highest increase in the number of job ads in this group. The number of job ads for which analytical thinking skill, and planning 
Table 12. Special qualifications required for candidates

\begin{tabular}{|c|c|c|}
\hline \multirow{2}{*}{ Special qualification } & \multicolumn{2}{|c|}{ \# of job ads } \\
\hline & Before COVID-19 & During COVID-19 \\
\hline \multicolumn{3}{|l|}{ Adaptation to team work } \\
\hline Specified & 550 & 1,112 \\
\hline Unspecified & 860 & 588 \\
\hline \multicolumn{3}{|l|}{ Adaptation to working Hours } \\
\hline Specified & 499 & 459 \\
\hline Unspecified & 911 & 1,241 \\
\hline \multicolumn{3}{|l|}{ Leadership ability } \\
\hline Specified & 201 & 598 \\
\hline Unspecified & 1,209 & 1,102 \\
\hline \multicolumn{3}{|l|}{ Communication ability } \\
\hline Specified & 803 & 1,285 \\
\hline Unspecified & 607 & 415 \\
\hline \multicolumn{3}{|l|}{ Analytical thinking skill } \\
\hline Specified & 378 & 741 \\
\hline Unspecified & 1,032 & 959 \\
\hline \multicolumn{3}{|l|}{ Planning and organisation skill } \\
\hline Specified & 319 & 496 \\
\hline Unspecified & 1,091 & 1,204 \\
\hline \multicolumn{3}{|l|}{ Problem solving ability } \\
\hline Specified & 888 & 1,369 \\
\hline Unspecified & 522 & 331 \\
\hline \multicolumn{3}{|l|}{ Ability to take responsibility } \\
\hline Specified & 798 & 1,025 \\
\hline Unspecified & 612 & 675 \\
\hline
\end{tabular}

Some job ads have the phrase "strong in human relations", and this statement is coded as "Communication Ability". Similar codes were made for other special qualifications in the table.

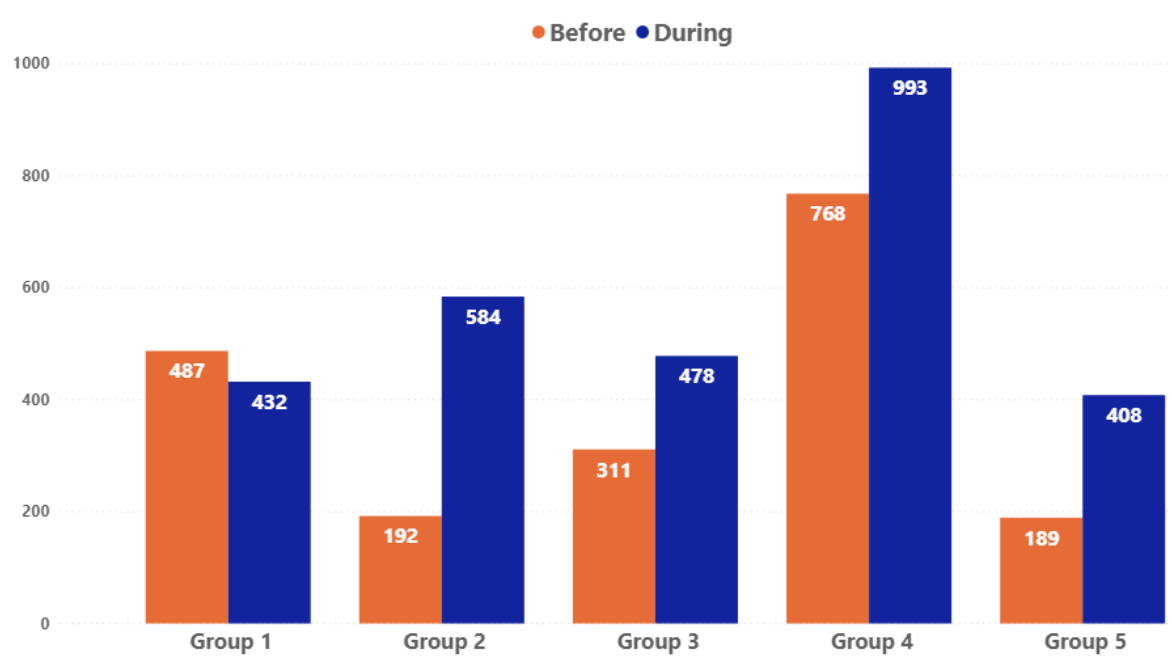

Figure 2. Groups by special qualifications.

and organisation skill are required together has increased, but the least increase in the number of job ads was in this group. Figure 2 shows that having the problem-solving ability and ability to take responsibility together is more important than other special qualification pairs in both periods. Also, leadership ability and communication ability have become an important requirement in the period during COVID-19. 
Other qualifications that are prominent in job ads and sought in candidates are given in Table 13. When the table is examined, it can be said that keeping up with the busy schedule, and open to learning and development are more stipulated in job ads in the post-pandemic period. Although it lost its place in the ranking, the number of job ads requiring reporting and analysis skills, adaptation to flexible working hours, and result-oriented has increased. The number of job ads where solution-oriented, sense of mission and responsibility, and long-term employment target attributes are stipulated separately has decreased in the period during COVID-19. The number of job ads for which all other qualifications are required separately has increased.

Considering the association rule, five groups have been formed regarding the other qualifications required for candidates in both periods. Group 1: Adaptation to flexible working hours- Keeping up with the busy schedule, Group 2: Reporting and analysis skills-Presentation skills-Strategic thinking skill, Group 3: Result oriented-Solution oriented-Customer oriented, Group 4: Innovator-Creative-Productive-Explorer, Group 5: Open to learning and development-Open to job sharing. The figure created by groups is below.

Table 13. Other qualifications required in job ads

\begin{tabular}{|c|c|c|c|}
\hline \multicolumn{2}{|l|}{ Before COVID-19 } & \multicolumn{2}{|l|}{ During COVID-19 } \\
\hline Other qualifications & \# of job ads & Other qualifications & \# of job ads \\
\hline Reporting and analysis skills & 106 & Keeping up with the busy schedule & 222 \\
\hline Adaptation to flexible working hours & 91 & Open to learning and development & 184 \\
\hline Keeping up with the busy schedule & 88 & Reporting and analysis skills & 151 \\
\hline Result-oriented & 81 & Adaptation to flexible working hours & 139 \\
\hline Innovator & 72 & Result-oriented & 117 \\
\hline Presentation skills & 69 & Presentation skills & 101 \\
\hline Solution-oriented & 59 & Customer-oriented & 89 \\
\hline Open to learning and development & 49 & Strategic thinking skill & 84 \\
\hline Sense of mission and responsibility & 44 & Use the time well & 80 \\
\hline Customer-oriented & 39 & Open to job sharing & 71 \\
\hline Strategic thinking skill & 37 & Productive & 58 \\
\hline Creative & 28 & Explorer & 44 \\
\hline Use the time well & 26 & Solution-oriented & 41 \\
\hline Long-term employment target & 21 & Creative & 38 \\
\hline Productive & 19 & Innovator & 32 \\
\hline Explorer & 16 & Sense of mission and responsibility & 27 \\
\hline Systematic and careful working ability & 14 & Systematic and careful working ability & 21 \\
\hline Open to job sharing & 11 & Long-term employment target & 14 \\
\hline
\end{tabular}

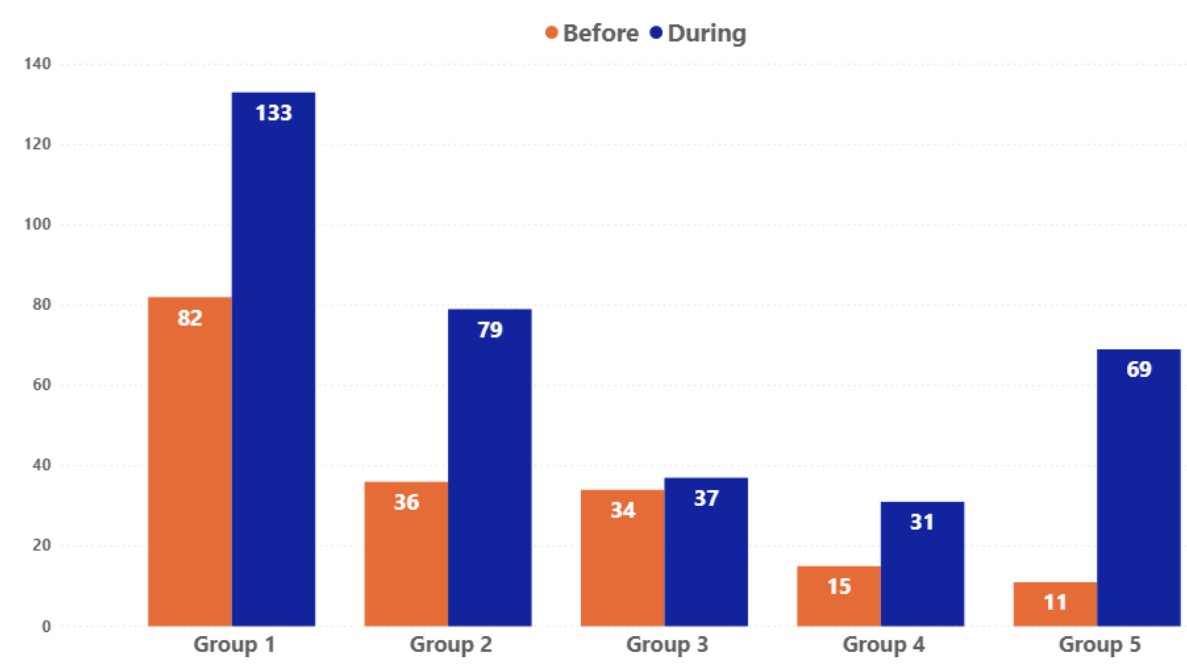

Figure 3. Groups by other qualifications. 
As can be seen in Figure 3, the number of job ads, in which both adaptation to flexible working hours and keeping up with the busy schedule are required together is higher in both periods. There were increases in all groups. The number of job ads for which open to learning and development, and open to job sharing are required together has increased, with the highest increase in the number of job ads in this group. The number of job ads for which result-oriented, solution-oriented, and customeroriented are required together has increased, but the least increase in the number of job ads was in this group. Also, the group order in both periods is the same, except for group 5. Figure 3 shows that adaptation to flexible working hours and keeping up with the busy schedule maintain their importance, open to learning and development, and open to job sharing have become an important requirement in the period during COVID-19.

\section{Discussion}

As far as we know, there is no study examining logistics job ads before and during COVID-19 in the literature. For this reason, in this section, first of all, the findings of the researches about job ads in general and the findings of this study will be compared in terms of similarities or differences. Then, we mentioned the findings of the researches about job ads during the COVID-19 period.

The findings of the study coincide with some of the similar studies in the literature. For example, Erdem and Gezen (2014) found that the opportunities provided for candidates (transportation, food and beverage, career, social activity) were not specified in the majority of the advertisements in their study of the job ads of tourism enterprises. Also, they found that the city with the highest number of job ads was Istanbul, the minimum level of education required for candidates was bachelor's degree, and the condition for the most stipulated experience in candidates was 1-5 years. Al et al. (2015) found that in the study in which they examined the job ads related to executive assistance, Istanbul was the province with the highest number of job ads and the minimum level of education required for candidates was bachelor's degree. Bacaksiz and Sönmez (2015) found that in the study in which they examined the job ads related to nurses, they found that the most frequently stated method of employment in the job ads is the full-time working method and the minimum level of education required by the candidates is bachelor's degree. The education level conditions found in this study on the periods before and during COVID-19 reveal similar results to previous studies. The number of job vacancy postings with Bachelor's Degree requirement in both period is quite high. This situation reveals that Bachelor's Degree is a crucial requirement in the sector. However, the differences in the number of job vacancy postings regarding the education level requirements between the two periods reveal interesting results. For example, considering the increase-decrease percentages of the number of job vacancy postings, the highest increase was in high school students with 247\%, while the second-highest increase was in the requirement for high school graduation with 146\%. Also, the highest decrease was in Ph.D. students with 42\%, while the second-highest decrease was in the requirement for Ph.D. with $32 \%$. Cacciolatti and Molinero (2013) found that candidates should have problem-solving skills in their study on supply chain job ads. In their study on corporate communication job ads, Kılınç and Akyol (2018) found that candidates should have the communication ability in more than half of the job ads. However, the findings of this study differ from those of similar studies. For example, Kotzab et al. (2018) found that in the study where they examined job ads related to logistics and supply chain management professionals, job ads included expressions related to cognitive competence and meta-competence rather than social skills. Bacaksiz and Sönmez (2015) found that in the study in which they examined the job ads related to nurses, they found that the most sought experience in candidates was between 1-2 years.

Holgersen et al. (2020) found that job ads decreased significantly during the pandemic period in Norway. Kahn et al. (2020) found that job ads reduced considerably during the pandemic period in the USA. Also, Hensvik et al. (2020) found that job ads decreased significantly during the pandemic period in Sweden. The findings of these three studies differ from the findings regarding the number of job ads obtained in this study. Kahn et al. (2020) stated that despite the significant decrease in job ads, there is no decrease in sectors such as retail and nursing. Therefore, the findings of this study are similar to the findings obtained by Kahn et al. (2020) in the retail industry. It would not be wrong to say that logistics and retailing are activities that complement each other, without one of which the other would be incomplete. Especially for the retail sector, one of the most important reasons for this is the increase in online shopping and the rise in the number of personnel needed in the face of increasing demand in this field. With the pandemic, it has become popular in many countries for people to obtain many needs from food to clothing online.

It has been observed that there are no significant differences between the logistics job vacancy postings examined in the period before COVID-19 and the period during COVID-19 in terms of the sector, province, department, experience requirement, manner of work and posting language. In other words, there is no significant difference between the two periods 
regarding these variables. UTIKAD's annual report supports this situation. Most of the enterprises in the sector stated that there is no significant change in the number of employees in 2020. Three out of four businesses stated that they are considering hiring new staff over the next six months. This rate has increased by 5\% compared to the previous research period. Also, the year 2020 was stable for the logistics sector. $46 \%$ of logistics enterprises stated that their business volume increased in 2020 . The rate of those who gave negative feedback in their jobs was also $25 \%$. None of the enterprises participating in the study used the expression "very negative" (UTIKAD 2021). The index regarding the human resources needs of the logistics sector increased in the third quarter of 2020. In parallel with the normalization steps, it has been observed that the increase in business volume has accelerated the need for human resources (KPMG 2020). The logistics industry experienced its golden age in the pandemic. Employment increased in the sector, which grew by 15 per cent in 2020 (7DENIZ 2021). However, the most significant difference between the two periods was in the distribution of job postings by positions. While the most desired position in the period before COVID-19 was Logistics Specialists, the most sought position in the period during COVID-19 was Sales Representative. The main reason for this important difference is that COVID-19 has changed the way of doing business and that people are forced to work in their homes or offices. This situation has increased the need for sales representatives in the sector and therefore this need has been reflected in the logistics job vacancy postings. Also, the need and demand for the storage supervisor have increased with COVID-19. The steady growth in online market shopping is already increasing the demand for cold storage and the need for a workforce in this area. The COVID-19 pandemic has increased online shopping, which will increase the need for a workforce in cold storage over the next five years (DCVELOCITY 2020). When the groups formed by considering the association rule are examined, it is seen that foreign language-computer skills, problem solving ability-ability to take responsibility, adapting to flexible working hours-keeping up with the busy schedule maintain their importance. In other words, the number of job vacancy postings for these qualities and features is also high during the COVID-19 period. However, the number of job vacancy postings containing open to learning and development-open to job sharing, leadership abilitycommunication ability, travel disability-driver's license increased more compared to other groups.

Due to the pandemic in many countries decided to close the border, including in Turkey. This situation had a particularly negative impact on road and air transport. Prices increased, especially in maritime transport. All these experiences point to the decrease in the business volumes of logistics companies and therefore, the need for employment. However, the increase in the number of job ads during the pandemic period found in this study seems to be a situation that cannot be caused by the developments in the sector. We predict that this seemingly contradictory situation may arise for two important reasons. First of all, although international logistics activities have been significantly disrupted, domestic logistics activities have increased largely due to the people turning to online shopping. It is possible that the demand for domestic logistics activities has increased significantly, and the sector may need more workforce to meet this demand. Second, largely normalisation steps were taken in Turkey on June 1st. With this development, the business volume and labour force requirement in the sector may increase even more. According to the Logistics Confidence Index, which is calculated by KPMG Turkey and the IU Department of Transportation and Logistics, the forecast for the third quarter for the Turkish logistics industry has increased positively. Also, expectations for business volume in the sector in the third quarter are strong. Sector representatives anticipate that the need for human resources will increase with the revival in air, road and maritime transportation (Marketing Türkiye 2020).

Data on the pandemic period in the study were obtained in the middle of July. This date corresponds to approximately 45 days after the normalisation steps were taken. Significant restrictions in Turkey in the period from March 16-June 1 was applied. During this period, layoffs occurred in many sectors. In the logistics sector, releases are likely to occur in parallel with the decrease in business volumes. Therefore, after the normalisation steps were taken, the recovery in the industry may have brought with it the efforts to replace people who were previously laid off. It is possible to partially attribute the increase in logistics job ads to these developments.

\section{Conclusion}

Along with globalisation, intense competition and technological developments throughout the world, applications using information and communication technologies have emerged in many sectors. Enterprises have to use the latest technology in their processes and activities to survive in the competitive market, to make a profit to continue their actions and not to fall behind the age. In addition to the technology and production equipment used, businesses need qualified human resources that will make a difference and make significant contributions to company processes. The selection of talented human resources is a difficult process, and businesses need to make careful choices in this process. Although human resource procurement is made through newspaper advertisements, employee references and similar methods in the historical process, it is mostly made in the 
electronic environment today. Businesses express the qualifications they look for in a candidate employer to fill vacancies using corporate websites and most career sites. Thanks to this method, while companies provide the opportunity to reach more candidates at a lower cost, candidates have the chance to apply for more than one job ads at the same time. At this point, the need to make a general inference regarding the job ads given by logistics companies has emerged concerning this process, which continues to be implemented in the sector. Therefore, with this study, it is aimed to reveal what qualities and characteristics of logistics companies need workforce and the features and qualities that potential employees who continue their education life in the field or who have completed their education life should have.

It is possible to summarise some findings related to job ads as a result of the content analysis as follows:

- The city with the most job ads is Istanbul in both periods.

- The sector with the most job ads is the transportation sector in both periods.

- The most sought position in the period before COVID-19 was Logistics Specialists, the most desired position in the period during COVID-19 was Sales Representative.

- The most sought experience requirement for candidates is 1-5 years in both periods.

- The most sought education level required for candidates is a bachelor's degree in both periods.

- The most frequently stated manner of work in the job ads is the full-time working method in both periods.

- According to the association rule, problem-solving ability and ability to take responsibility together is more important than other special qualification pairs in both periods.

- Also, foreign language knowledge and computer skills are important and essential key features for candidates in both periods.

- Adaptation to flexible working hours, and keeping up with the busy schedule is more important than other qualification pairs in both periods.

To address the questions that are the starting point of the study, it is seen that the number of logistics job ads increased in the COVID-19 period compared to the previous year. It is understood that the results for both periods are very close to each other. However, it can be said that the number of advertisements in which the qualifications sought in candidates are specified has increased significantly. It is seen that the number of job ads in which special capabilities such as adaptation to working hours, leadership ability, and planning and organisation skill are specified did not increase much. Considering these three special features and the low level of increase in question, it is understood that these three features are not very important in candidates when performing logistics works where it is possible to do business remotely with the effect of digitalisation. Despite the significant increases in other special features, it would not be wrong to interpret the low-level increase in the three special characteristics mentioned above as a digitisation effect.

Admittedly, the study has some limitations. The data were obtained only from the website and the job ads between 11.07.2019-18.07.2019 (before COVID-19) and 13.07.2020-20.07.2020 (during COVID-19). Only the job ads in Kariyer.net are taken into consideration. Due to the job ads that will be added to the website in the following days or removed from the website as a result of hiring the appropriate candidate, data may be obtained at different dates or in different numbers. Researchers can use different websites where logistics job ads are available in further studies. They can also review job ads from multiple sources, taking into account newspaper ads as well as websites. In the study, only frequency analysis was done by coding. Researchers can also apply different analyses according to the data they obtain. Also, some special attribute pairs were created by considering the association rule. Researchers can create different trait pairs by considering the association rule. They can make an in-depth analysis of a particular feature pair.

\section{Acknowledgements}

The authors thank the anonymous reviewers for their suggestions.

\section{References}

Aday, S., Aday, M. S., 2020. Impact of COVID-19 on the food supply chain. Food Quality and Safety 4, 167-180.

Agrawal, R., Imielinski, T., Swami, A., 1993. Mining association rules between sets of items in large databases. Proceedings of the ACM SIGMOD International Conference on Management of Data (ACMSIGMOD '93), Washington, DC. 
Al, Ö., Karaca, M. F., Irk, E., 2015. Yönetici asistanlığı için iş kriterleri analizi: Kariyer.net örneği. Electronic Journal of Vocational Colleges 14, 29-42.

Bacaksız, F. E., Sönmez, B., 2015. İnsan kaynakları web sitelerinde yer alan hemşire iş ilanlarının incelenmesi. Sağlık ve Hemşirelik Yönetimi Dergisi 3, 112-122.

Bayraktar, O., 2015. Osmanlıca gazetelerdeki personel ilanlarının içerik değerlendirmesi: 1909-1924. Amme İdaresi Dergisi 48, 79-96.

BCG [Boston Consulting Group], 2020. Leading sales through the COVID-19 crisis. Ava1lable at: https://www.bcg. com/publications/2020/stabilize-increase-sales-through-covid-crisis

Beltekin, N., 2014. İşgücü talebi ve eğitim ilişkisi üzerine bir analiz (iş ilanları örneği). Elektronik Sosyal Bilimler Dergisi 13, 226-240.

Bennett, R., 2002. Employers' demands for personal transferable skills in graduates: A content analysis of 1000 job advertisements and an associated empirical study. Journal of Vocational Education \& Training 54, 457-476.

Birant, D., Kut, A., Ventura, M., Altınok, H., Altınok, B., Altınok, E., Ihlamur, M., 2010. İş zekası çözümleri için çok boyutlu birliktelik kuralları analizi. Akademik Bilişim Konferans Bildirileri 10, 256.

BLS [U.S. Bureau OF Labor Statıstıcs], 2019. Occupational outlook handbook. Available at: https://www.bls.gov/ooh/businessand-financial/logisticians.htm

Cacciolatti, L., Molinero, C. M., 2013. Analysing the demand for supply chain jobs through job advertisements. Kent Business School, Working Paper Series No. 264.

Cao, X., 2020. COVID-19: Immunopathology and its implications for therapy. Nature Reviews Immunology 20, 269-270.

Çavdar, H., Çavdar, M., 2010. İşletmelerde işgören bulma ve seçme aşamaları. Journal of Naval Sciences and Engineering 6, 79-93.

Çetin, M., Akar Şahingöz, S., 2019. İnsan kaynakları web sitelerinde aş̧̧lara yönelik iş ilanları üzerine bir inceleme. Uluslararası Sosyal Araştırmalar Dergisi 12, 726-734.

CBS Local, 2021. Coronavirus: Out of work? These places are hiring. Available at: https://miami.cbslocal.com/2021/03/ 22/coronavirus-out-of-work-these-places-are-hiring/

Clyde, L. A., 2002. An instructional role for librarians: An overview and content analysis of job advertisements. Australian Academic \& Research Libraries 33, 150-167.

Croneis, K. S., Henderson, P., 2002. Electronic and digital librarian positions: A content analysis of announcements from 1990 through 2000. The Journal of Academic Librarianship 28, 232-237.

Cullen, W., Gulati, G., Kelly, B. D., 2020. Mental health in the COVID-19 pandemic. QJM: An International Journal of Medicine 113, 311-312.

D’Alessandro, B., 2018. Third-party logistics' hiring manager strategies to recruit supply-chain professionals. Ph.D. Dissertation, Walden University, USA.

Daniel, S. J., 2020. Education and the COVID-19 pandemic. Prospects 49, 91-96.

DCVELOCITY, 2020. COVID-19 to accelerate demand for cold storage. Available at: https://www.dcvelocity.com/ articles/45734-covid-19-to-accelerate-demand-for-cold-storage

Dobroszek, J., Mourao, P., Grzesiak, L., 2019. Identification of the similarities and differences of logistics controller, manager and specialist: A study based on a content analysis. The International Journal of Logistics Management 30, 261-283.

Doğan, B., Erol, B., Buldu, A., 2014. Sigortacılık sektöründe müşteri ilişkileri yönetimi için birliktelik kuralı kullanılması. Marmara Fen Bilimleri Dergisi 3, 20140901.

Doğan, S., Tuncer, M., 2019. Otel personeli iş ilanlarında aranan nitelik ve becerilere yönelik bir araştırma. Business \& Management Studies: An International Journal 6, 1231-1251.

Donthu, N., Gustafsson, A., 2020. Effects of COVID-19 on business and research. Journal of Business Research 117, 284-289.

Duncan, D. F., 1989. Content analysis in health education research: An introduction to purposes and methods. Health Education 20, 27-31.

Erdem, B., Gezen, T., 2014. Turizm işletmelerine yönelik iş ilanlarinin içerik analizi yöntemiyle incelenmesi. Uluslararası Yönetim İktisat ve İşletme Dergisi 10, 19-42.

Ertaş, Ç., 2018. Turizm sektöründeki nitelikli çalışan eksikliğinde turizm işletmelerinin payı: İş ilanları üzerinden bir inceleme. Adıyaman Üniversitesi Sosyal Bilimler Enstitüsü Dergisi 30, 1143-1172.

Finn, T. A., Strickland, D. E., 1982. A content analysis of beverage alcohol advertising. II. Television advertising. Journal of Studies on Alcohol 43, 964-989. 
Gallavin, M., Truex, D., Kvasny, L., 2004. Changing patterns in IT skill sets 1988-2003: A content analysis of classified advertisements. The Database for Advances Systems 35, 64-87.

Gaur, A., Kumar, M., 2018. A systematic approach to conducting review studies: An assessment of content analysis in 25 years of IB research. Journal of World Business 53, 280-289.

Gibson, B. J., Lorin Cook, R., 2001. Hiring practices in US third-party logistics firms. International Journal of Physical Distribution \& Logistics Management 31, 714-732.

Giglietto, F., Selva, D., 2014. Second screen and participation: A content analysis on a full season dataset of tweets. Journal of Communication 64, 260-277.

Grigoriadis, N., 2014. Skills and competencies employers require from supply chain graduates: A job advertisements content analysis. Master Thesis, Linnaeus University, Sweden.

Guan, D., Wang, D., Hallegatte, S., Davis, S. J., Huo, J., Li, S., Bai, Y., Lei, T., Xue, Q., Coffman, D., Cheng, D., Chen, P., Liang, X., Xu, B., Lu, X., Wang, S., Hubacek, K., Gong, P., 2020. Global supply-chain effects of COVID-19 control measures. Nature Human Behaviour 4, 577-587.

Hartsough, R., Laffal, J., 1970. Content analysis of scientific writings. The Journal of General Psychology 83, 193-206.

Hensvik, L., Le Barbanchon, T., Rathelot, R., 2020. Job search during the COVID-19 crisis. CAGE Online Working Paper No. 473.

Heske, H., 1986. Political geographers of the past III German geographical research in the Nazi period: A content analysis of the major geography journals, 1925-1945. Political Geography Quarterly 5, 267-281.

Holgersen, H., Jia, Z., Svenkerud, S., 2020. Labor demand during the COVID-19 crisis in Norway: Evidence from vacancy posting data. Available at: https://papers.ssrn.com/sol3/papers.cfm?abstract_id=3663479

Holsti, O. R., 1969. Content Analysis for the Social Sciences and Humanities. Addison-Wesley, Reading, MA.

Kahn, L. B., Lange, F., Wiczer, D. G., 2020. Labor demand in the time of COVID-19: Evidence from vacancy postings and UI claims. NBER Working Paper No. w27061.

Kariyer, 2019. Hakkımızda. Available at: https://www.kariyer.net/kurumsal/hakkimizda

Keung, S. W. C., Pine, R., 2000. Changes in hotel industry recruitment as reflected by content analysis of newspaper advertisements. Asia Pacific Journal of Tourism Research 5, 57-69.

Kılınç, Ö., Akyol, M., 2018. Kurumsal iletişim iş ilanları üzerine bir değerlendirme. İnönü Üniversitesi İletişim Fakültesi Elektronik Dergisi 3, 65-82.

Klumpp, M., 2016. Logistics Qualification: Best-Practice for a Knowledge-Intensive Service Industry. Logistics and Supply Chain Innovation, Springer, Switzerland.

Koban, E., Keser, H. Y., 2013. Rekabet edebilirlikte türk lojistik sektörünün istihdam yapısının analizi ve istihdama yönelik devlet destekleri. Çalışma İlişkileri Dergisi 4, 32-43.

Kondracki, N. L., Wellman, N. S., Amundson, D. R., 2002. Content analysis: Review of methods and their applications in nutrition education. Journal of Nutrition Education and Behavior 34, 224-230.

Kotzab, H., Teller, C., Bourlakis, M., Wünsche, S., 2018. Key competences of logistics and SCM professionals: The lifelong learning perspective. Supply Chain Management: An International Journal 23, 50-64.

Kovács, G., Tatham, P., Larson, P. D., 2012. What skills are needed to be a humanitarian logistician? Journal of Business Logistics 33, 245-258.

KPMG, 2020. Confidence rises in logistics. Available at: https://home.kpmg/tr/tr/home/medya/press-releases/2020/12/lojistik te-guven-yukseliyor.html

LaLonde, B. J., 1990. Update logistics skills for the future. Transportation \& Distribution 31, 46-48.

Larson, C. U., 1974. A content analysis of media reporting of the watergate hearings. Communication Research 1, 440-448.

Lau, Y., Jiamian, Z., Ng Adolf, K. Y., Panahi, R., 2020. Implications of a pandemic outbreak risk: A discussion on China's emergency logistics in the era of coronavirus disease 2019 (COVID-19). Journal of International Logistics and Trade 18, 127-135.

Lin, C. C., Chang, C. H., 2018. Evaluating skill requirement for logistics operation practitioners: Based on the perceptions of logistics service providers and academics in Taiwan. The Asian Journal of Shipping and Logistics 34, 328-336.

Loske, D., 2020. The impact of COVID-19 on transport volume and freight capacity dynamics: An empirical analysis in German food retail logistics. Transportation Research Interdisciplinary Perspectives 6, 100165.

Marketing Türkiye, 2020. Lojistikte hareket başladı. Available at: https://www.marketingturkiye.com.tr/haberler/lojistiktehareket-basladi/ 
Mastro, D. E., Stern, S. R., 2003. Representations of race in television commercials: A content analysis of prime-time advertising. Journal of Broadcasting \& Electronic Media 47, 638-647.

Murphy, P. R., Poist, R. F., 1991. A comparison of headhunter and practitioner views regarding skill requirements of seniorlevel logistics professionals. Logistics and Transportation Review 27, 277-295.

Öksüz, B., 2011. E-işe alım sürecinde kurumsal web sitelerinin kullanımı ve konu üzerine bir araştırma. Uluslararası Yönetim İktisat ve İşletme Dergisi 7, 267-283.

Özdemir, S. S., Polat, E., Met, Ö. L., 2015. Bodrum'da faaliyet gösteren konaklama işletmelerince verilen iş ilanlarindaki işgören niteliklerinin analizi. Sosyal ve Beşeri Bilimler Araştırmaları Dergisi 16, 121-138.

Özkan, Y., Bingöl, U., Mete, H., 2018. Türkiye'de elektronik istihdam platformlarında yayınlanan bilişim sektörü iş ilanlarının nitel analizi (2017-2018). Anemon Muş Alparslan Üniversitesi Sosyal Bilimler Dergisi 6, 289-296.

Peres, Y., Meivar, H., 1986. Self-presentation during courtship: A content analysis of classified advertisements in Israel. Journal of Comparative Family Studies 17, 19-32.

Peterson, R. T., 1994. Depiction of idealized youth lifestyles in magazine advertisements: A content analysis. Journal of Business Ethics 13, 259-269.

Pfefferbaum, B., North, C. S., 2020. Mental health and the COVID-19 pandemic. New England Journal of Medicine 383, 510512.

Poist, R. F., Scheraga, C. A., Semeijn, J., 2001. Preparation of logistics managers for the contemporary environment of the European Union. International Journal of Physical Distribution \& Logistics Management 31, 487-505.

Razzaque, M. A., Sirat, M. S. B., 2001. Skill requirements: Perception of the senior Asian logisticians. International Journal of Physical Distribution \& Logistics Management 31, 374-395.

Singh, S., Kumar, R., Panchal, R., Tiwari, M. K., 2020. Impact of COVID-19 on logistics systems and disruptions in food supply chain. International Journal of Production Research 59, 1993-2008.

Sodhi, M. S., Son, B. G., 2010. Content analysis of OR job advertisements to infer required skills. Journal of the Operational Research Society 61, 1315-1327.

Söylemez, İ., Doğan, A., Özcan, U., 2016. Trafik kazalarında birliktelik kuralı analizi: Ankara ili örneği. Ege Academic Review $16,11-20$.

Stead, B. A., 1978. A content analysis of the Journal of Business Communication: Toward a body of knowledge. The Journal of Business Communication 15, 45-51.

Stevenson, T. H., Swayne, L. E., 2011. Is the changing status of African Americans in the B2B buying center reflected in trade journal advertising? Journal of Advertising 40, 101-122.

Sun, X., Wandelt, S., Zhang, A., 2020a. Dissection of a singularity: The impact of COVID-19 on aviation. Journal of International Logistics and Trade 18, 113-125.

Sun, X., Wandelt, S., Zhang, A., 2020b. How did COVID-19 impact air transportation? A first peek through the lens of complex networks. Journal of Air Transport Management 89, 101928.

Temiz, N., Cingöz, K., 2015. İşgören seçim sürecindeki kritik faaliyetlerin analitik hiyerarşi süreci ile değerlendirilmesi. Dokuz Eylül Üniversitesi Sosyal Bilimler Enstitüsü Dergisi 17, 531-553.

Thai, V. V., Cahoon, S., Tran, H. T., 2011. Skill requirements for logistics professionals: Findings and implications. Asia Pacific Journal of Marketing and Logistics 23, 553-574.

Todd, P. A., McKeen, J. D., Gallupe, R. B., 1995. The evolution of IS job skills: A content analysis of IS job advertisements from 1970 to 1990. MIS Quarterly 19, 1-27.

Trunick, P. A., 1998. New demands for tomorrow's manager. Transportation \& Distribution 39, 18-19.

Tu, S. C., Lin, S., 1999. Impact of politics on Chinese periodicals, 1960-1995. Behavioral \& Social Sciences Librarian 17, 2153.

TUIK [Türkiye İstatistik Kurumu], 2021. Ücretli çalışan istatistikleri. Available at: https://data.tuik.gov.tr/Bulten/Index?p= Ucretli-Calisan-Istatistikleri-Ocak-2021-37498\&dil=1

Türkal, İ., Taşcıoğlu, R., 2018. Türkiye'de halkla ilişkilerin stratejik rolü: İnsan kaynakları sitelerindeki iş ilanları üzerine bir inceleme. Atatürk İletişim Dergisi 15, 37-58.

Türkal, İ., Taşcıoğlu, R., 2020. Özel ve gönüllü kuruluşlar bağlamında "halkla ilişkiler" meslek algısı: İş ilanları üzerine bir inceleme. Uluslararası Kültürel ve Sosyal Araştırmalar Dergisi 6, 38-51.

UTIKAD, 2021. Trends and expectations in the logistics industry 2020 report. Available at: https://www.utikad.org.tr/ images/HizmetDergi/utikaddergisi24sayi-03178.pdf 
Yilmaz, Ö. D., 2020. Konaklama işletmelerinde odalar bölümü iş ilanları üzerine bir araştırma. Ahi Evran Üniversitesi Sosyal Bilimler Enstitüsü Dergisi 6, 480-495.

Yücel, Ç. P., Bal, Y., 2018. Elektronik işe alım sürecinde sosyal paylaşım sitelerinin kullanımı ve bir uygulama. Uluslararası Sosyal Araştırmalar Dergisi 11, 897-917.

Wang, Z., Ye, X., Tsou, M. H., 2016. Spatial, temporal, and content analysis of Twitter for wildfire hazards. Natural Hazards 83, 523-540.

Waters, D., 2003. Logistics: An Introduction to Supply Chain Management. Palgrave Macmillan, New York.

Worthington, R. L., Soth-McNett, A. M., Moreno, M. V., 2007. Multicultural counseling competencies research: A 20-year content analysis. Journal of Counseling Psychology 54, 351-361.

Wu, Y. C., Chen, Y. J., Wang, J. S., 2004. Skill requirements for logistics licenses. IEEE International Engineering Management Conference 3, 1198-1202.

7DENIZ, 2021. The logistics industry is experiencing its golden age. Available at: https://www.7deniz.net/haber-lojistiksektoru-altin-cagini-yasiyor-37585.html 